\title{
Philanthropy in Education: What's the Cost?
}

\author{
Nick Waterman
}

\begin{abstract}
The hollowing-out of the state has rendered countries more susceptible to influences of external policy actors. Neo-liberal strategies of the New Public Management and the New Policy Agenda emphasise the importance of alternative service providers to the state. A resultant "contract culture" facilitates not only gap-filling in service delivery, but also penetration of policy spaces by non-state actors. Globalisation has also served to diminish the state and facilitate external policy actors. This paper adopts a critical perspective on the potential impacts of philanthropic support for education on public policy. Individual and corporate philanthropy challenge public policy-making autonomy, especially in developing countries. Involvement in public policy-making and dissemination and implementation of policy through transnational policy networks further contribute to erosion of the sovereignty of the state. Influence on public policy can occur either through coercion or voluntarism on a push-pull basis, whereby philanthropy may push recipients into policy conformity through selective and policybased funding, or pull recipients to formulate polices that are compatible with individual and corporate policy agendas.
\end{abstract}

Keywords: Philanthropy; Education; New Public Management; New Policy Agenda; Global Public Private Partnerships

\section{INTRODUCTION}

Many of the issues surrounding philanthropy in education are unexplored. Although philanthropy may provide much-needed resources for gap-filling in service delivery, this paper suggests that large individual and corporate philanthropic entities or Big Philanthropy may constitute powerful external policy actors, with implications for public policy-making and autonomy of nation-states especially developing countries. Philanthropic activity influences public policy in two major ways. Firstly, by funding research for evidenced-based policy development. Secondly, through participation in Global Public Private Partnerships (GPPPs) which act as conduits for lobbying, advocacy, and policy dissemination.

The ideological foundations of the New Public Management (NPM) and New Policy Agenda (NPA) emerged in the late twentieth century which provided strategies for reinventing the state. In shrinking the resources and power of the state and denuding public policy-making capability, the state is increasingly permeable to external policy influences including GPPPs. These provide conduits for philanthropic influence over education policy and practice. The vulnerability and susceptibility of the state to external policy actors, especially developing countries arguably results in states' penetration of their domestic policy space by "philanthropic colonialism".

In contrast to older-style "legacy" philanthropy based on a lifetime's accumulation of assets and late-in-life or posthumous donations, new and hybrid forms of more complex philanthropy have emerged which involve various and different philanthropic purposes, mechanisms of disbursement, anticipated results and ownership. This in includes so-called "philanthrocapitalism", that is application of business principles into philanthropic endeavours 
and "venture philanthropy", whereby the goal is often to make a desired financial return on financial investments whilst also having a positive social impact.

The nature, extent and impact of individual, corporate and national philanthropic interventions may differ, as well as their procedures, mechanisms and management. However, the emergence of mega-billionaires and mega-philanthropy raises important questions. This paper focuses on concerns regarding philanthropic foundations in particular, and the potential costs.

\section{NATURE AND EXTENT OF PHILANTHROPY}

This section examines philanthropic foundations. These may be individual, corporate and national. Often there are overlapping governance arrangements and interests, but for the purposes of clarity these are described separately with the main focus on foundations established by wealthy individuals.

\section{Individual Philanthropy}

A century ago America's attorney-general denounced the oil mogul Rockefeller's proposed foundation as "an indefinite scheme for perpetuating vast wealth" that was "entirely inconsistent with the public interest" (Callahan 2017: 4). The reservations are twofold. Firstly, that foundations are a vehicle for increasing and perpetuating wealth, and secondly that individual and corporate wealth is used to change public policy and in doing so bypasses established procedures for public policy-making and oversight mechanisms, including regulatory scrutiny and civil society consultative processes.

A century after the Rockefeller Foundation was established, similar concerns have been expressed. In the United States (US), Callahan (2017:157) notes that;

"Nowhere have philanthropists taken a more muscular approach to influencing public life than education. And nowhere have they stirred more fears that philanthropy is becoming yet a tool for the wealthy to speak more loudly than anyone else."

Recently Oxfam (2017) reported that the collective net worth of the wealthiest eight men is equivalent to that of the poorest half of the world's population i.e. 3.6 billion people. Ironically these mega-billionaires are also mega-philanthropists, funding a number of worthy causes including education to address pressing social problems.

Callahan (2017) points out that the wealth of mega-billionaires has increased enormously in recent years, and that instruments such as foundations are often vehicles for retaining wealth within a small family's circle, and exercising national and international influence over the long term. There is also concern that certain activities of hedge-funds' managers and tax avoidance by transnational corporations (TNCs) may deprive national treasuries of funds to address policy problems (or exacerbates public policy problems) that individual and corporate philanthropists seek to address through their philanthropy.

Individual philanthropy has gained prominence in recent years with the announcement of the Giving Pledge, the brainchild of Bill Gates and Warren Buffett whereby wealthy individuals have pledged to give away more than half their wealth for notable causes, including education. The Office of Philanthropic Partnerships funded by the Bill and Melinda Gates Foundation acts to coordinate the who's who of the Giving Pledge. This continues a trend of ultra-high net worth individuals making large financial contributions through foundations. Such individuals include household names of successful entrepreneurs, including founders and heads of major TNCs in investment management, the media, ICT and retail. They also include celebrities in the music industry, sport, and former politicians. 
Many individual mega-philanthropists have seen the value of their assets soar since the financial crash a decade ago, which continue to rise despite making their Giving Pledge. This is at a time when public expenditure is being squeezed in many countries resulting in spending cuts in public services, and when many families' household incomes are under severe pressure. Such pledges have courted controversy, not least because of the governance instruments used and perceived lack of transparency. For example, Mark Zuckerberg, co-founder of Facebook, and arguably one of the most famous of the Giving Pledge signatories, pledged in 2015 to give away $99 \%$ of his fortune of an estimated 45 billion US dollars. However, the Chan Zuckerberg Initiative, established to dispose of such enormous wealth is a new limited liability company and not subject to the same disclosure rules as non-profits organisations and foundations. Such a vehicle allegedly enables avoids tax obligations and legal oversight, a phenomenon termed "dark philanthropic money" (Callahan, 2017:295).

There are over 90,000 foundations in the US alone, which control more than 700 billion US dollars in assets (Callahan 2017:205). Over half of all US foundations are controlled by families. The assets of foundations exclude the assets managed by consulting firms and management services companies to advise and manage "Big Philanthropy". Companies overseeing these Donor-Advised Funds (DAFs) include Donors.Trust, Tides Foundation, New Venture Fund, Fidelity Charitable, Schwarb Charitable, JPMorgan Chase Philanthropy Centre, and the Proteus Fund which manages large and small philanthropists' donations in pooled funds for specific social sectors and causes. In 2015, DAFs totalled 13 billion US dollars. This "shadow giving system" (Callahan, 2017:295) involving huge sums of money has raised concerns regarding motives, governance and transparency issues.

\section{Corporate and National Philanthropy}

Corporate philanthropy includes well-known brand-names in manufacturing, foodstuffs, and the banking sector. Corporate Social Investment with the aim to uplift individuals and communities has become an aspect of Corporate Social Responsibility concerned with broader responses to the "3Ps", that is, profit, people and the planet. Companies may establish foundations as separate entities from their core commercial business, although these foundations may have close relationships with their for-profit activities. Philanthropic foundations also include nations, whereby state-level foundations often derived from oilwealth engage in supporting various education and other causes.

The opportunities for philanthropic foundations and their impacts have arguably been enhanced by the diminished role and resources of the hollowed-out state. These include influence over public policy-making.

\section{THE HOLLOWED-OUT STATE}

This section discusses NPM, NPA and globalisation in contributing to the hollowed-out state.

\section{The New Public Management}

NPM had by the late 1990s become "a truly global paradigm" (Borins 1997 in McCourt, 2001:236) Although NPM may have differing orientations a major and consistent feature is the state's diminishing role in public service delivery, which is increasingly undertaken by publicprivate partnerships and non-governmental organisations (NGOs) (McGarvey, 2001). The change from public ownership, public subsidies and directly provided services has led to "a hollowing out of the state", with the loss of capability by governments to effectively control public policy-making (Gray 2000 in McGarvey, 2001:951). The culture, conditions and context of public service delivery is transformed, with corporatisation, privatisation and other market mechanisms replacing the primacy of the state in service delivery. The marketisation of service 
delivery includes restructuring of the public sector through commercialisation or outright privatisation of state-owned enterprises, downsizing the civil service and decentralisation.

NPM is deemed to undermine core public sector values of universality, accessibility and accountability in favour of more selective, for-profit service delivery dominated by the private sector. Privatisation is deemed to have undermined the state and strengthened elites, through what (Hibou, 1999:71) terms the "economy of plunder", that is, "the acquisition by the representatives of public authority of economic resources for private purposes." Where downsizing has occurred, the struggle for power, privilege and patronage intensifies. Consequently, NPM has invariably become a battleground for asset-stripping and national theft that diverts attention and resources of the state.

The introduction of NPM has often been accompanied by strategies for decentralisation in its various political and administrative forms. This includes the use of NGOs for alternative service delivery. Although decentralisation ostensibly brings service delivery closer to local communities with greater transparency and accountability, Craig and Porter (2002:65) suggest that there is abundant evidence of the "tyranny" effects of decentralisation. The battle for largesse between and within levels of governance has served to decentralise corruption and create bitter feuds between the centre and decentralised structures. By turning upon itself, the state is weakened by internal discord.

Through the "new magistry" (Turner and Hulme, 1997:234) arising from the plunder of state resources, the state is weakened and becomes increasingly subject to the influence of more powerful or emergent elites that control resources and power. Public policy-making is likely to become more partisan, with elites pandering to policy transfer driven by external policy actors as a strategy of self-enrichment.

\section{The New Policy Agenda}

NPA also emphasises the importance of free markets and a reduced role for the state (Commins, 1997:14). It also emerged in the 1990s, emphasising the potential for economic development and democratising role of NGOs especially in developing countries. NPA was deemed to be able fill the void left by the hollowed-out state as a mechanism for development and considered to be an "alternative development paradigm' (Zaidi, 1999:259).

Consequently, NPA has resulted in the scaling-up of the NGO sector, including rapid institutional growth of both international NGOs and country-specific NGOs Given the increasing involvement of NGOs in service delivery, a growing separation has tended to emerge between the state as responsible for the policy and regulatory environment and actual public service providers. A major consequence of this has been:

"to fragment the sovereignty of the state and to dilute its responsibility by dissociating those who apply policy from those who are formally held responsible to society as whole", (Hibou, 1999:95).

Using NGOs as a deliberate substitution for service delivery by the state has arguably given rise to various patron-client relationships between funders and NGOs, leading to further erosion of administrative and institutional capacity of the state.

A "contract-culture" (Robinson, 1997:62) has emerged, whereby NGOs compete for funding, which is invariably subject to "strictures and conditionality" (Olowu, 2005:10). Funding within the context of a 'contract culture' tends to enable funders to "buy" legitimacy for their own policy agendas (Paul, 1996:1), and also acts as a powerful impetus for NGOs to formulate 
policies consistent with funders' policy agendas. This provides the opportunity for influence over policy-making by external policy actors. They can influence public policy-making either through coercion or voluntarism on a push-pull basis, whereby they push recipients into policy conformity through selective and policy-based funding, or pull recipients to formulate polices that are compatible with their own.

The increased role of NGOs leads to an erosion of administrative and institutional capacity of the state. Furthermore, policy actors may deliberately embrace privatisation and marketisation because of increased opportunities for malfeasance (Turner and Hulme, 1997:234). Hence, they become inextricably integrated into national and international structures of power and largesse. In this regard, public policy-making becomes a vehicle for the private acquisition of public wealth, rather than for improved societal welfare.

The overall consequence of NPM and NPA is arguably greater influence over the state by vested partisan interests. These factors impact upon the nature and extent of public policy-making as the state increasingly looks outwards, appealing to external international policy agendas in order to sustain the national inflows of resources. This situation increasingly involves complex governance arrangements of policy-making being characterised by a vertical axis of overlapping influences (Kaplan 1999 in Kickbusch and Buse, 2001).

The vertical axis of overlapping influences of the governance of public policy-making includes individual and corporate wealth. Such influences may not always be perceived as benign.

\section{Globalisation}

The process of globalisation is not necessarily a new phenomenon and arguably began with the development of mercantilism in the fifteenth century. A distinguishing feature of current globalisation from the mercantile capitalism of approximately 500 years ago and the onset of monopoly capitalism in the twentieth century is the intensity and extent of its impacts. Contemporary globalisation may be seen as the virtual universalism of global capitalism, including the integration of markets and accelerated cross-border flows of finance and people. Although there are various perspectives on the nature and impact of globalisation, it may be regarded as expressing the multitude and magnitude of technological, political, social and cultural global changes, including the dominance of market forces (Kickbusch and Buse, 2001). Held et al. (1999 in Kickbusch and Buse, 2001:702) define globalisation as a process, or set of processes:

"which embodies a transformation in the spatial organisation of social relations and transactions - assessed in terms of their extensity, intensity, velocity and impact generating transcontinental or interregional flows and networks of activity, interaction and exercise of power."

Adar and Ajulu (2002:4) argue that globalisation has rendered the notion of the nation-state, with control over its territory and population as an autonomous actor, all but meaningless, They state that:

"contemporary globalisation has imposed the unprecedented power of a few overwhelmingly and powerful countries upon the many weaker in the international system", (Adar and Ajulu, 2002:4).

Globalisation often creates volatility and uncertainty and destabilises the domestic policy context (Abedian, 1998). Globalised forces impact disproportionately upon developing countries that have smaller and more vulnerable economies and less capacity for appropriate policy responses. The World Trade Organisation serves to enforce globalisation including trade 
liberalisation, open-ness to foreign direct investment, privatisation and deregulation. The Bretton Woods Institutions of the World Bank and International Monetary Fund are also highly instrumental in imposing the new economic order and have become increasingly politicized in pursuit of policy agendas (Adar and Ajulu, 2002).

Globalisation has subjected national boundaries to increasing external policy penetration (Bache and Taylor, 2003). Thus, globalisation has circumscribed, constrained and redefined the state's ability to manage its own affairs. This includes constraints on its "internal sovereignty", such as room for manoeuvre in public policy-making (Reinicke and Witte 1999 in Buse et al., 2002:253).

Globalisation limits the national sovereignty of a hollowed-out state, where policy agendas are often controlled by supranational bodies. These reduce room for manoeuvre in producing home-grown policy responses to pressing policy problems. In this context, countries are malleable under the influence of external policy actors to policy transfer. Given the weakness of the state in public policy-making, countries are often subject to varying degrees of coercion as a result of conditionalities. The growing loss of a state's control over its affairs through globalisation has tended to foster arrangements between national governments, International Governance Organisations such as the United Nations (UN), and TNCs, all of which may exert influence over national public policy-making.

Internationalisation is in a sense a trade-off between a loss of national sovereignty and a preserved measure of subsidiarity, or some national or sub-national autonomy within broader supranational structure. It generally refers to international cooperation in addressing international problems that impact on individual states (Fidler, 1997). Internationalisation may be defined as:

"...a process through which the authority and autonomy of the nation-state is challenged or supplanted by structures, process or policy developments which cut across national boundaries", (Moran and Wood, 1996:125).

Public policy-making is increasingly subject to the participation of international institutions that operate on a global, regional or sub-regional basis. Although global, regional and subregional groupings of states and supranational bodies may emerge to pool collective interests and to guard against negative impacts of globalisation, they may bring additional constraints on public policy-making.

Internationalisation, including regionalism, is likely to be dominated by the more powerful and influential member countries and organisations, even amongst groupings of developing countries. Many supranational institutions may have policy agendas that are difficult for countries to ignore (Common, 1998). Thus, internationalisation has also subjected national boundaries to increasing external policy penetration (Bache and Taylor, 2003).

Declining ability of governments to address policy problems and provide public services, especially when such problems themselves may have transnational dimensions such as Out-ofSchool Children and gender inequity in service delivery. Supranational institutions such as International Governance Organisations have emerged to "manage" policy development and implementation and which may have their own policy agendas. Such supranational institutions play a pivotal role in policy transfer. 


\section{POLICY TRANSFER}

The impact of NPM, NPA and globalisation has created opportunities for philanthropic foundations to become important policy actors. Policy actors may be defined as; "individuals or groups of individuals with the capacity to influence, either formally or informally, the policy-making process", (Lee et al., 2002:13).

Networks represent a mode for the international dissemination of policy paradigms and come in various shapes and sizes. Policy networks may be formal institutions or informal, ad hoc arrangements of policy actors. These may be termed 'policy communities', defined as "relatively small groups of participants with an interest in a specific set of issues" (Booysen and Erasmus, (2001:247). Stone (2004: 559) uses the term Global Public Policy Networks, which may include or overlap with what are variously termed "global policy advocacy coalitions", or "transnational knowledge networks" (Deacon 2008:27).

The emphasis on networks, particularly those of a global nature, is that they have an international reach and impact. Individual network members, factions within networks or networks as a whole can be construed as "policy entrepreneurs" "who seek to initiate dynamic policy change (Mintrom, 1997:739). Policy entrepreneurs engage in a variety of strategies to win support for ideas which include "identifying problems, networking in policy circles, shaping the terms of policy debates, and building coalitions" (Mintrom, 1997:739). They may comprise international foundations, as well as consultancy firms, think tanks, universities and NGOs which may be funded by foundations. Policy entrepreneurs may be instrumental in both policy development and policy transfer.

Dolowitz and Marsh (2000:17) suggest that inappropriate transfer occurs where insufficient attention has been paid to economic, political and social contexts of the "borrowing" national or sub-national unit. Successful and timeous transfer depends on a host of internal and external factors, including the political, bureaucratic and financial resources of the recipient country (Bache and Taylor, 2003).

The conformity in general of education policies to an international education policy agenda reflects an international policy convergence. In conditions of a weak state that lacks policymaking capacity, there may be considerable pressures for government to "take policy" rather than to "make policy" (Mather, 2001:5-6). Making policy implies substantive participation in policy-making and ownership of such policy. Taking policy implies concurring with policy agendas established by other policy actors and accepting their preferred policy options. Policy convergence reflects successful policy transfer (Dolowitz and Marsh 2000). Stone (2004:564) refers to the "transnationalisation of policy", which includes both the nature of policy content and also the supranational processes involved in shaping policy content.

Regarding the transfer of policy content, Dolowitz and Marsh (2000) state that there are four different gradations, that is: copying, which involves direct and complete transfer; emulation, which involves transfer of the ideas behind the policy; combinations, which involve mixtures of different policies; inspiration, where policy elsewhere may inspire a national policy change. Regarding the processes involved in policy transfer, Dolowitz and Marsh, (1998:38) draw the following distinction between voluntary and coercive transfer:

"Voluntary transfer implies that rational, calculating actors desire a change and actively seek policies to satisfy their needs. Coercive transfer, or conditionality, occurs when policy makers are forced by the actions of outsiders to engage in transfer." 
It is unlikely that a hollowed-out state will adopt or formulate policy without regard to financial and other resources. Hence, policies may be designed that deliberately appeal to agendas of international policy hubs as a magnet to attract resources, without necessarily concurring with their policy priorities.

In addition to direct or indirect coercion, the policy transfer process may involve more flexible and nebulous forms of influence exerted through policy networks, defined as:

"the means by which organisations individually and in coalition can project their ideas into policy thinking across states and within global or regional forums", (Stone 2004:560).

Transfer of education policy in a context of dependency and funding volatility is problematic. Furthermore, the potential lack of policy fit to national and sub-national circumstances risks policy failure.

\section{PHILANTHROPY AND ITS IMPACTS ON PUBLIC POLICY}

This section examines the impact of philanthropy on public policy vis-à-vis policy development and policy transfer.

\section{Philanthropy and policy-development}

Philanthropic entities may influence public policy-making vis-à-vis knowledge management and developing evidenced-based proposals, including funding research. Research may have ideological leanings and policy biases, which Rich and Weaver, (1996 in Anderson, 2003:63) term the "politicisation of expertise". Philanthropic entities may not only define what is considered to be relevant and worthwhile research, but also fund research for public policy that has been politically and financially pre-determined. Research agendas, problem-definition, agenda-setting, devising of proposals and policy adoption may be heavily influenced by research. Funding research, co-opting academics, grant-making to universities and supporting think-tanks to set the terms of public policy debate and promote or exclude specific policy choices conveniently enable philanthropists to circumvent unwarranted publicity and exposure that may arise from overtly political contributions and outward support for controversial causes. As Callahan (2017:65) states:

"think-tanks operate as the mother-ships of ideological movements on the left or the right - the best exceed at framing the terms of public debates and putting specific ideas on the national agenda(or knocking other ideas off)."

The emergence of a policy window where policy problems, policy proposals and an appropriate political climate coalesce may be heavily influenced by research agendas and research findings. Conversely, research may be influenced by policy-making processes and preexisting policy. Policy actors are likely to ensure that there is congruence between research and policy-making, with each influencing the other to some extent. The politicisation of expertise is thus an aspect of a range of activities that may anchor public policy-making within foundations' data collection and information-management. Callahan (2017:67) argues that;

"the most savvy donors know they can often have the greatest influence by funding upstream, shaping what ideas get on the legislative agenda in the first place."

Up-stream funding and the politicisation of expertise enable philanthropic entities to be proactive and comprehensive in their approach to policy-making, facilitating their dominance over national and international policy agendas. This influence is amplified by participation in transnational networks such as GPPS 


\section{Philanthropy and policy transfer}

The multiplicity of partnerships, including alliances, networks, coalitions and consortiums reflect a host of different and overlapping organisational relationships in policy transfer. These include partnerships involving formal agreements between philanthropic entities, governments, the UN and GPPPs, which involve partnerships with private sector organisations that transcend national boundaries. GPPPs have become an increasingly important in the landscape of service delivery and public policy-making. Their importance is acknowledged by the former mayor of New York and billionaire, Michael Bloomberg, who founded the Bloomberg Family Foundation and who states that philanthropic organisations can help push their agendas "by leveraging our resources, and forming partnerships with government" ((undated in Callahan, 2017: 14).

For example, a large for-profit international education company which builds and operates a large number of schools in many countries also has a consultancy arm that works with public and private sector clients on school improvement. It also has a philanthropic foundation (the founder is a UN Goodwill Ambassador) contributing to policy-making and providing grants to organisations. This is highly commendable. However, where a single organisation essentially combines philanthropy with for-profit activities, the relationships between them may potentially risk becoming entangled with perceived (if not actual) conflicts of interest.

The UN Foundation was launched in 1998 with a one billion US dollars gift from Ted Turner, the former media magnate and founder of the Turner Foundation. The United Nations Foundation was established to support United Nations causes and encourage other donors to support the UN in its activities. Since its beginning, the United Nations Foundation has provided grants in order to support UN goals and is the largest source of private funding to the UN. In conjunction with the UN, the United Nations Foundation established the United Nations Fund for International Partnerships to serve as the UN counterpart to the Foundation. The United Nations Fund for International Partnerships, also established in 1998, facilitates partnerships with companies, foundations and civil society organisations. It has collected more than 1.2 billion US dollars including from other foundations, corporations, NGOs, and individuals. The Foundation also works with UN partners in order to provide policy recommendations and project proposals.

During the last two decades, international cooperation and broader organisational participation in international and national socio-economic affairs have expanded to include a greater diversity of policy actors in partnership with UN agencies. The UN has explicitly recognised the need for the UN and PSOs to work together, and the 2003 Maputo Declaration by African heads of state and government included the desirability of promoting partnerships with UN agencies and PSOs. The World Bank Corporate Citizen Program initially established in 1996 was designed to facilitate the role of big business in transforming key social sectors including education in developing countries. The next year, following a meeting with private individuals and heads of foundations;

"It was, however, felt that corporate citizenship should not be viewed as philanthropic effort but rather as a rational and self-interested business strategy" (Jimenez, 1998).

Although partnerships with the UN may facilitate greater availability of much-needed resources, they may entail mixed policy agendas that unduly impact on the perceived integrity of global institutions. An international coalition of NGOs has stated that certain relationships between the UN and PSOs; "are promoting a vision of corporate-driven globalisation that threatens the mission and integrity of the UN", (Third World Network 2000 in Hong, 2000:77). 
Despite what is ostensibly an important private sector contribution to a resource-poor education environment, it is perhaps salutary to consider critical perspectives on the impact of GPPPs. Buse and Walt (2002:52) argue that GPPPs are pump-priming mechanisms to establish, develop and expand markets for goods and services. The commercially strategic value of Corporate Social Investment for corporate philanthropic entities is indicated by Chaparro and Gevers (undated in Buse and Walt, 2002:54), who state that:

"traditional philanthropy is out-dated. Companies realize that investment in the wellbeing of their host communities is more and more of a strategic interest; it helps them to build a stable reputation and a brand; and it critically reduces the risk inherent to any foreign investment."

Hence, partnerships with the UN may be a vehicle whereby vested ideological and commercial interests piggyback on the connections and the resources of UN agencies in order to further their own policy agendas. Partnerships are ways in which TNCs can establish bridgeheads for competitive advantage and eventually marketise service delivery. They may also provide conduits for policy transfer.

\section{PHILANTHROPY - WHAT'S THE COST?}

This sub-section tentatively explores actual and potential costs of Big Philanthropy on education policy and practice.

\section{Distorted education policy and practice}

The interventions of Big Philanthropy do not necessarily accord with the needs, interests or wishes of a larger education constituency of potential beneficiaries and other stakeholders. For example, Callahan (2017) argues that in the US at least, the wealthy tend to be more fiscally conservative and socially liberal than the general population as whole. Furthermore, they tend to have a stronger belief in market solutions and technocratic fixes to pressing policy problems. At institutional levels, secondary and less influential policy actors including civil society organisations are likely to have limited participation in GPPS and are likely to be eclipsed by more influential policy actors. "Chequebook activism" (Callahan, 2017:290) serves to enhance the influence of the mega-rich through their financial resources, whilst marginalising much of the rest of civil society.

Citing a 2014 article in the Washington Post, Callahan (2017:65) draws attention to what one commentator has termed the "billionaire boys club" and in reference to Bill Gates that;

"the idea that the richest man in America can purchase - and working closely with the US Department of Education - impose new and untested academic standards on the nation's public schools is a national scandal".

John Paulson, a hedge-fund manager who made billions in the financial crash a decade ago, gave 400 million US dollars in 2015 as a tax-exempt gift to Harvard University, the richest of all American universities. This apparently comes at a time when grants to needy students are being cut. Although few would dispute Paulson's right to give, one wonders if such a gift to what is already the richest university in the US advances equitable education service delivery, and whether this is a policy concern anyway.

\section{Lack of policy fit}

Individual and corporate philanthropists arguably may approach philanthropy in much the same way they approach business. In the case of those involved in ICT and hedge-funds their predisposition is arguably for immediacy and interventions that are transformative and largescale. However, this involves risk, which may be anathema to a development discourse which 
emphasises (in theory at least) evidence-based interventions, context-specific participatory engagement, and piloting or small-scale initial actions for lesson-drawing prior to up-scaling. Building of low-cost community-based schools, the introduction of appropriate technology for blended learning and development of innovative teacher-training strategies do not necessarily lend themselves to risky interventions.

In conditions of resource-constraints, many countries are vulnerable to uncritical policy transfer. Some polices may be counter-productive, or even highly destructive, exacerbating policy problems and undermining the resources and capacity of the state and other national and sub-national policy actors to address them, resulting in policy failure. Warren Buffet has stated that philanthropy is society's "risk capital" implying perhaps that recipients are guinea pigs of Big Philanthropy.

\section{Effectiveness of interventions}

The Walton family, heirs to the Walmart retail fortune, and others have given large amounts of money to charter schools in the US, which are publicly funded, privately administered and sometimes for-profit. However, in Newark, New Jersey, a top-down school-reform strategy "disregarded community priorities, generated wide resentment, exacerbated inequity and defunded public schools" (Birn, 2017). Fiennes (2017) suggests that Mark Zuckerberg's US\$ 100-million gift to schools in Newark, New Jersey, reportedly achieved little.

The author of this paper is aware of a situation whereby the Middle East foundation funded a UN agency for laudable work in a particular country, but other donors were also funding the same UN agency to implement the same or similar activities. The funds were not pooled, but rather the UN agency was in the unenviable position of having to disentangle and quantify the effectiveness of the philanthropic funds from other discrete donor funds, a task made more difficult when the donor-funded activities were the same or overlapping and involved the same implementing staff.

Inappropriate education infrastructure developments are not uncommon. The author this paper is also aware of a large teacher-training institute partly funded by philanthropic funds in a particular country that remained almost totally unused for years due to lack of demand, and being flooded in heavy rains and falling into decay due to the inappropriate location. This was complemented by another teacher-training institute that suffered a similar fate, as did a purpose-built and equipped vocational training centre and a number of schools in the same country.

Donors are rarely publicly chastised for under-performing, yet the misplaced opportunity cost is borne by intended beneficiaries, not by the funder (Fiennes, 2017). Some grants schemes create so much administration that recipients may be are better off without them, and that some donors' decisions seem to be no better than if beneficiaries were chosen at random, with the funded work achieving no more than rejected proposals (Fiennes, 2017). Issues relating to selection of whom and what to fund, inappropriate interventions, and burdensome bureaucratic overheads and excessive transaction costs challenge the effectiveness of interventions at policy development and implementation levels. Fiennes (2017) notes that recipients of funds are increasingly scrutinised, but the effectiveness of philanthropic funding is not.

There are few studies on philanthropic effectiveness. However, Fiennes (2017:187) noted that the Centre for Effective Philanthropy in Cambridge, Massachusetts, found that the time spent on proposals for, and the management of a number of small grants took far longer than time 
spent on one large aggregated grant. The nfpSynergy consultancy found that UK charities value smaller unconditional funds rather than slightly larger grants, suggesting that attaching conditionalities to donations reduces their value. The Shell Foundation found that three times as many of its grants succeeded when the Foundation was heavily involved in creating and managing the work than when it had funded work based on a proposal from a charitable organisation (Fiennes, 2017).

The role of biases in awarding philanthropic funds has not been examined adequately. Almost all donors make their decisions subjectively, either by soliciting the opinions of experts or interviewing applicants (Fiennes, 2017). Given the scant evidence about which ways of giving and what size of grants for specific purposes over what durations are most effective, Fiennes (2017:187) suggests that more research on what makes for effective philanthropy is required and calls for a "science of philanthropy".

\section{Challenges to policy governance}

Partnerships are particularly problematic in terms of policy responsibility, accountability and transparency, given that they rest with partnerships, not necessarily with individual partners. This raises issues of transparency in the relationships between partners, the operating mechanisms of partnerships and partnerships' relations with other policy actors. The increasing advent of partnerships involving TNCs shifts the fulcrum away from the public good with elected political representatives and appointed officials that are at least nominally accountable to the general public. There is a move in influence towards entrepreneurs and corporate managers with concerns for market share, profitability and shareholder value. This comes at a time when many in civil society perceive increased marginalisation and being elbowed aside by wealthy and powerful elites who have become "activist donors" or "super citizens" shaping and re-shaping public policy and public institutions (Callahan, 2017).

The influence on policy governance is not necessarily confined to top-down coercive pressure or financial enticements. It may occur bottom-up. The author of this paper is familiar with a situation whereby a country's education minister was insistent upon the participation in the project steering committee of a representative of a large philanthropic organisation (from whom he was desperate to secure more funds) which was also supporting education in the same country. The donor funding the project disagreed, on the grounds that it was inappropriate for a donor to have a say in the implementation of a project funded by another donor, especially as there was no formal arrangement for cross-membership of steering committees. This apparent example of entryism reflects in a specific localised way attempted penetration of a philanthropic organisation's potential interests into the relationship between an education ministry and its primary donor.

\section{Public policy and sovereignty}

Public policy-making is increasingly subject to participation of international institutions that operate on a global basis. In the context of limits to national sovereignty of hollowed-out states, policy agendas are often controlled by GPPS and other supranational bodies. Policydependency undermines development of appropriate policy-making processes, local ownership of policies and commitment to policy success. More generally, it further undermines the sovereignty of the nation-state.

Although relationships between national and international elites are diffused through a myriad of political and economic connections and interests, powerful sub-national and national elites may be part of a myriad of transnational extra-territorial elites (Bauman 1998 in Lee et al., 2002). Friedman (1995 in Common, 1998) argues that a global elite has emerged which 
includes government ministers, aid officials, and representatives of international organisations such as the UN. One might also add philanthropic foundations. Although perceptions of existence a single global public policy elite may be fanciful, national and international interlocking networks of wealth, power and influence are visibly expressed at elite gatherings such as the Bilderberg Group and the World Economic Forum.

\section{CONCLUSIONS}

Comparatively well-resourced and globally influential philanthropic foundations and GPPPs may find it easy to encourage the hollowed-out state and sub-national structures into predetermined policy positions. In being oriented to the policy agendas of other policy actors, the state's policy-making may be inclined to lack a sustainable institutional base and become managerially and administratively fractured. This is likely to negatively impact on clear and focused policy and risks policy failure due to insufficient resources for implementation of adopted policy.

Given the influence of Big Philanthropy and GPPPs, the locus of power in policy-making is invariably distant from national and sub-national domains. In the absence of policy-making capacity and under pressure from external policy actors, the state and sub-national structures have public accountability for policy-making but not necessarily full responsibility. Big Philanthropy may undertake responsibility for policy-making, but is unaccountable to local civil society and parliaments.

Direct and indirect penetration and occupation of policy space displaces sovereignty in public policy-making. If Big Philanthropy is not to be perceived as a Trojan horse for increased wealth, power and influence in international affairs by those who already have considerable leverage, more work needs to be done to satisfy the requirements for effective and sustainable public policy-making, especially transparency, responsibility and accountability.

\section{References}

Abedian, I (1998) “Economic globalisation: the consequences for fiscal management”, in Abedian, I and Biggs, M (eds) Economic Globalisation and Fiscal Policy, Cape Town, Oxford University Press Southern Africa.

Adar, K G and Ajulu, R (2002) “Southern African states' foreign policy and foreign policy-making process: an introductory contextualisation, in Ajar, K G and Ajulu, R (eds) Globalisation and Emerging Trends in African States' Foreign Policy-Making Process: a comparative perspective of Southern Africa, Aldershot, Ashgate.

Anderson, J E (2003) Public Policymaking, Fifth Edition, Boston, Houghton Miffin Company.

Birn, A-E (2017) "Philanthropy: the politics of giving”, in International Weekly Journal of Science, Issue 7648 (544), pps. 31 - 32. [Online]. Available at:

http://www.nature.com/nature/journal/v544/n7648/full/544031a.html?foxtrotcallback=true

Bache I and Taylor A (2003). "The politics of resistance: reconstructing higher education in Kosovo", Journal of Public Policy, 25 (3), pps. 279-300

Booysen, S and Erasmus, E (2001) "Public policy-making", in Venter, A (ed) Government and Politics in the New South Africa, Second Edition, Pretoria, Van Schaik.

Buse, K, Drager N, Fustikian, S and Lee, K (2002) “Globalisation and health policy: trends and opportunities”, in Lee, K, Buse, K and Fustikian (eds) Health Policy in a Globalising World, Cambridge, Cambridge University Press.

Buse, K and Walt, G (2002) "Globalisation and multilateral public-private health partnerships: issues for health policy”, in Lee, K, Buse, K and Fustikian, S (eds) Health Policy in a Globalising World, Cambridge, Cambridge University Press.

Callahan, D (2017) The Givers: wealth, power and philanthropy in a new gilded age, New York, Alfred A Knopf.

Commins, S (1997) “World Vision International and donors: too close for comfort?”, in Hulme, D and Edwards, M NGOs, States and Donors: too close for comfort?, Basingstoke, Macmillan 
Common, R (1998) “The new public management and policy transfer: the role of international organisations", in Minogue, M, Polidano, C and Hulme, D (eds) Beyond the New Public Management: changing ideas in practices and governance, Cheltenham, Edward Elgar.

Craig D and Porter, D (2002). "Poverty reduction strategy papers: a new convergence”, in World Development 31 (1), pps. 53-69. Deacon

Deacon B (2008). “Global and regional social governance”, in Yeates, N (ed) Understanding Global Social Policy, Bristol, Policy Press.

Diklitch S (1998). The Elusive Promise of NGOs in Africa, Basingstoke, Macmillan.

Dolowitz DP and Marsh D (1998). "Policy transfer: a framework for comparative analysis", in Minogue, M, Polidano, C and Hulme, D (eds) Beyond the New Public Management: changing ideas in practices and governance, Cheltenham, Edward Elgar.

Dolowitz DP and Marsh D (2000). "Learning from abroad: the role of policy transfer in contemporary policymaking", in Governance: An International Journal of Policy and Administration, 13 (1), pps. 5-24.

Edwards M and Hulme D (1995). "NGO performance and accountability: introduction and overview", in Edwards, $\mathrm{M}$ and Hulme, D (eds) NonGovernmental Organisations -Performance and Accountability: beyond the magic bullet, London, Earthscan.

Evans M (2010). "Policy transfer in critical perspective" in Evans, M (ed) New Directions in Policy Transfer, London, Routledge

Fidler, D P (1997) "The globalisation of public health: emerging infectious diseases and international relations", Indiana Journal of Global Legal Studies, 5 (1), pps 11-51.

Fiennes, C (2017) “We need a science of philanthropy”, International Weekly Journal of Science, Issue 7657, (546), p. 187. [Online]. Available at: https://www.nature.com/news/we-need-a-science-of-philanthropy-

1.22100?WT.mc_id=FBK_NA_1706_FHWVSCIENCEPHILANTHROPY_PORTFOLIO

Hibou B (1999). “The 'social capital' of the state as an agent of deception”, in Bayart J F, Ellis, S and Hibou, B The Criminalisation of the State in Africa, Oxford, James Currey. Jonker

Hong, E (2000) Globalisation and the Impact on Health: a Third World view. [Online]. Available at: http://www.phmovement.org/pdf/pubs/phm-pubs-hong.pdf

Jimenez, G (1998) “The World Bank and corporate citizenship”, in Alliance Magazine, June, 1998. [Online]. Available at: http://www.alliancemagazine.org/feature/the-world-bank-and-corporate-citizenship/

Jonker A (2001). "Challenges and imperatives facing modern government", in Van Niekerk, D and Van der Waldt, G and Jonker, A Governance, Politics and Policy in South Africa, Cape Town, Oxford University Press. Lesotho

Kickbusch, I and Buse, K (2001) "Global influences and global responses: international health at the turn of the twenty-first century", in Merson, M H, Black, R E and Mills, A J (eds) International Public Health: diseases, programs, systems and policies, Gaithesburg, MD, Aspen.

Lee, K, Fustukian, S and Buse, K (2002) "An introduction to global health policy", in Lee, K, Buse, K and Fustukian, $S$ (eds) Health Policy in a Globalising World, Cambridge, Cambridge University Press.

Osaghae, E (1994) "Introduction: between the individual and the state in Africa”, in Osaghae, E (ed) Between State and Civil Society in Africa: perspectives on development, Dakar, Council for Development of Social Research in Africa.

Mather, J (2001) Public policy analysis: national coordination. [Online]. Available at:

http://www.hlss.mmu.ac.uk/pap/politics/unit\%20docs/public\%20policy\%20analysisL10.htm

McGarvey N (2001). "Reviews - new perspectives on accountability", Public Administration, 79 (2), pps. 949-959.

Menahem, G (1998) "Policy paradigms, policy networks and water policy in Israel”, Journal of Public Policy, 18 (3), pps 283-310.

Minogue M (1998). "Changing the state: concepts and practice in the reform of the public sector", in Minogue, M, Polidano, $C$ and Hulme, D Beyond the New Public Management: changing ideas and practices in governance, Cheltenham, Edward Elgar.

Mintrom, M (1997). "Policy entrepreneurs and the diffusion of innovations", in American Journal of Political Science, 41 (3), pps. 738 - 770. 
Moran, M and Wood, B (1996) “The globalisation of health care policy?”, in Gummett, P (ed) Globalisation and Public Policy, Cheltenham, Edward Elgar.

Olowu D (2005). “Introduction: New Public Management - an African reform paradigm?”, African Development, 27 (3-4), pps.1-16.

Oxfam (2017) An Economy for the 99\%: it's time to build a human economy that benefits everyone, not just the privileged few. [Online]. Available at: https://www.oxfam.org/sites/www.oxfam.org/files/file_attachments/bpeconomy-for-99-percent-160117-en.pdf

Paul J A (1996) The World Bank and NGOs. [Online]. Available at: http://www.globalpolicy.org/ngos/analysis/wrldbank.htm

Robinson, M (1997) “Privatising the voluntary sector: NGOs as public service contractors”, in Hulme, D and Edwards, E (eds) NGOs, States and Donors: to close for comfort?, Basingstoke, Macmillan.

Stone D (2004). “Transfer agents and global networks in the 'transationalisation' of policy”, in ذournal of European Social Policy, 11 (3), pps. 546- 566.

Turner M and Hulme D (1997) Governance, Administration and Development: making the state work, West Hartford, CN, Kumarian Press.

Waterman, N (2015) "Education policy-making - wither the state as policy actor", in Global Advanced Research Journal of Educational Research and Review, 4 (7), pps. 114 - 122. [Online]. Available at: http://garj.org/garjerr/7/2015/4/7/education-policy-making-wither-the-state-as-policy-actor

Zaidi SA (1999). "NGO failure and the need to bring back the state”, Journal of International Development 11, pps. 259-271. 